\title{
Fragile X Syndrome: The GABAergic System and Circuit Dysfunction
}

\author{
Scott M. Paluszkiewicz ${ }^{a, b}$ Brandon S. Martin ${ }^{a, b}$ Molly M. Huntsman ${ }^{a}$ \\ ${ }^{a}$ Center for Neuroscience Research, Children's National Medical Center, and ${ }^{b}$ Interdisciplinary Program in \\ Neuroscience, Georgetown University Medical Center, Washington, D.C., USA
}

\section{Key Words}

Inhibition · Fragile X mental retardation protein · Synapse • Developmental disorder • Autism spectrum disorders • Cerebral cortex $\cdot$ Amygdala

\begin{abstract}
Fragile $\mathrm{X}$ syndrome (FXS) is a neurodevelopmental disorder characterized by intellectual disability, sensory hypersensitivity, and high incidences of autism spectrum disorders and epilepsy. These phenotypes are suggestive of defects in neural circuit development and imbalances in excitatory glutamatergic and inhibitory GABAergic neurotransmission. While alterations in excitatory synapse function and plasticity are well-established in Fmr 1 knockout (KO) mouse models of FXS, a number of recent electrophysiological and molecular studies now identify prominent defects in inhibitory GABAergic transmission in behaviorally relevant forebrain regions such as the amygdala, cortex, and hippocampus. In this review, we summarize evidence for GABAergic system dysfunction in FXS patients and Fmr1 KO mouse models alike. We then discuss some of the known developmental roles of GABAergic signaling, as well as the development and refinement of GABAergic synapses as a framework for understanding potential causes of mature circuit dysfunction. Finally, we highlight the GABAergic system as a relevant target for the treatment of FXS.

Copyright @ 2011 S. Karger AG, Basel
\end{abstract}

\section{Introduction}

Fragile X syndrome (FXS) is the most common form of inherited intellectual disability and a leading genetic cause of autism [de Vries et al., 1998; Hagerman et al., 2009]. The genetic basis of FXS is a CGG repeat expansion mutation in the Fmrl gene [Verkerk et al., 1991], which codes for fragile $\mathrm{X}$ mental retardation protein (FMRP), an RNA-binding protein involved in the transport and translational regulation of a wide array of cellular and synaptic proteins [Bagni and Greenough, 2005; Bassell and Warren, 2008]. In addition to cognitive disability and features of autism spectrum disorders (ASD), FXS patients are characterized by anxiety, sensory hypersensitivity, and elevated incidences of epilepsy [BerryKravis, 2002; Berry-Kravis et al., 2010; Hagerman and Stafstrom, 2009; Hagerman et al., 2009; Miller et al., 1999; Musumeci et al., 1999], consistent with circuit dysfunction and imbalances in excitatory and inhibitory transmission in various brain regions, including the amygdala, cortex, and hippocampus. Excitatory-inhibitory imbalances and synaptic dysfunction are proposed to play a central role in a number of pathological states, including FXS and ASD [Belmonte and Bourgeron, 2006; Moy and Nadler, 2008; Rubenstein and Merzenich, 2003; Zoghbi, 2003].

\section{KARGER}

() 2011 S. Karger AG, Basel

Fax +4161306 1234

E-Mail karger@karger.ch

www.karger.com
Accessible online at: www.karger.com/dne
Molly M. Huntsman

Center for Neuroscience Research

Children's National Medical Center

Washington, DC 20010 (USA)

Tel. +1 202476 4324, E-Mail MHuntsman@cnmcresearch.org 
Inhibitory neurotransmission in the CNS is mediated by populations of neurons that synthesize and release GABA, which exerts its effects through two subtypes of receptor: the ionotropic $\mathrm{GABA}_{\mathrm{A}}$ receptors and the metabotropic G-protein-coupled $\mathrm{GABA}_{B}$ receptors. In mature neurons, $\mathrm{GABA}_{\mathrm{A}}$ receptors mediate postsynaptic membrane hyperpolarization by permitting intracellular $\mathrm{Cl}^{-}$influx in the presence of GABA. These postsynaptic receptors comprise two categories: synaptic receptors that produce fast, phasic inhibition in response to relatively high concentrations (mM) of synaptically released neurotransmitter, and extrasynaptic receptors that produce a slow, persistent tonic conductance in response to low neurotransmitter concentrations (nM to low $\mu \mathrm{M}$ ) in the extrasynaptic space [for a review, see Farrant and Nusser, 2005]. GABA ${ }_{B}$ receptor activation likewise hyperpolarizes the postsynaptic membrane by activating $\mathrm{G}$-protein-coupled inwardly rectifying $\mathrm{K}^{+}$channels to produce slow inhibitory currents [Padgett and Slesinger, 2010]. In addition to its role as a postsynaptic inhibitory neurotransmitter, GABA can also modulate neurotransmitter release in an autocrine or paracrine fashion, via distinct mechanisms at presynaptic $\mathrm{GABA}_{\mathrm{A}}$ and $\mathrm{GABA}_{\mathrm{B}}$ receptors [Bettler et al., 2004; Trigo et al., 2008]. GABAergic neurons exhibit striking morphological, biochemical, and physiological diversity [Kawaguchi and Kubota, 1997; Markram et al., 2004; Somogyi and Klausberger, 2005]. These populations are further defined by their tendency to form distinct inhibitory circuits based on reciprocal electrical connectivity [Beierlein et al., 2003; Galarreta and Hestrin, 1999; Gibson et al., 1999], as well as their propensity to synapse onto a specific subcellular compartment of target neurons [Kawaguchi and Kubota, 1997; Muller et al., 2006, 2007; Somogyi et al., 1998], indicating a high degree of circuit refinement in the mature brain. This refinement is further indicated by the fact that inhibitory synapses at different subcellular compartments are defined by the expression of different $\mathrm{GABA}_{\mathrm{A}}$ receptor subunits [Fritschy and Brunig, 2003; Fritschy et al., 1998; Klausberger et al., 2002; Nusser et al., 1996; Nyiri et al., 2001]. Thus, GABAergic inhibitory neurons comprise highly specific circuits acting to control cellular and network excitability, direct the flow of information, and generate neural synchrony and oscillations involved in a number of cognitive processes [Cardin et al., 2009; Porter et al., 2001; Sohal et al., 2009; Wang, 2010]. Given these crucial roles of inhibitory neurons in normal circuit function, it is not surprising that interneuron loss or dysfunction has been implicated in a number of disease states, including FXS,
ASD, Rett syndrome, schizophrenia, and epilepsy [Buckmaster and Jongen-Rêlo, 1999; Chao et al., 2010; Cossart et al., 2001; Gogolla et al., 2009; Lewis et al., 2005; Selby et al., 2007].

In view of the importance of inhibitory transmission in normal circuit function and its relevance to a number of neurodevelopmental disorders, we discuss elements of the GABAergic system that are disrupted in the Fmrl knockout (KO) mouse model of FXS, with a particular focus on postsynaptic $\mathrm{GABA}_{\mathrm{A}}$ receptor-mediated transmission, emphasizing their relevance for the neurological phenotypes of the syndrome. In addition, given the importance of GABA in synapse and circuit development and maturation [Akerman and Cline, 2007; BenAri, 2002; Huang, 2009], we discuss how defects in this system might contribute to abnormal circuit development. Finally, we summarize studies in patients and animal models that illuminate the GABAergic system as a viable and important therapeutic target for the treatment of FXS.

\section{Crucial GABAergic Synapse Components Are Dysregulated in FXS}

FMRP is widely expressed throughout the brain, in both neurons and glia [Devys et al., 1993; Feng et al., 1997; Olmos-Serrano et al., 2010; Wang et al., 2004], and deletion of FMRP results in widespread alterations in the expression of mRNA and proteins from a number of functional categories, including cation channels, adhesion molecules, neurotransmitter receptors, and components of the vesicular transport and release machinery [Brown et al., 2001; Liao et al., 2008; Schütt et al., 2009], suggesting broad cellular and synaptic alterations in the FXS brain. Importantly, FMRP is broadly expressed in GABAergic neuron populations [Feng et al., 1997; Olmos-Serrano et al., 2010], indicating that it is involved in normal interneuron maturation and function.

The GABAergic system was first implicated in the pathogenesis of FXS based on studies of $\mathrm{GABA}_{\mathrm{A}}$ receptor expression in Fmrl KO mice. Functional $\mathrm{GABA}_{\mathrm{A}}$ receptors are heteropentamers, and subunit composition is an important determinant of inhibitory transmission, dictating receptor characteristics such as response kinetics, subcellular localization, and sensitivity to a number of clinically important compounds [Hevers and Lüddens, 1998; Rudolph and Möhler, 2006; Sieghart and Sperk, 2002]. Following the initial finding that FMRP can bind $\delta$ subunit mRNA [Miyashiro et al., 2003], a number of 


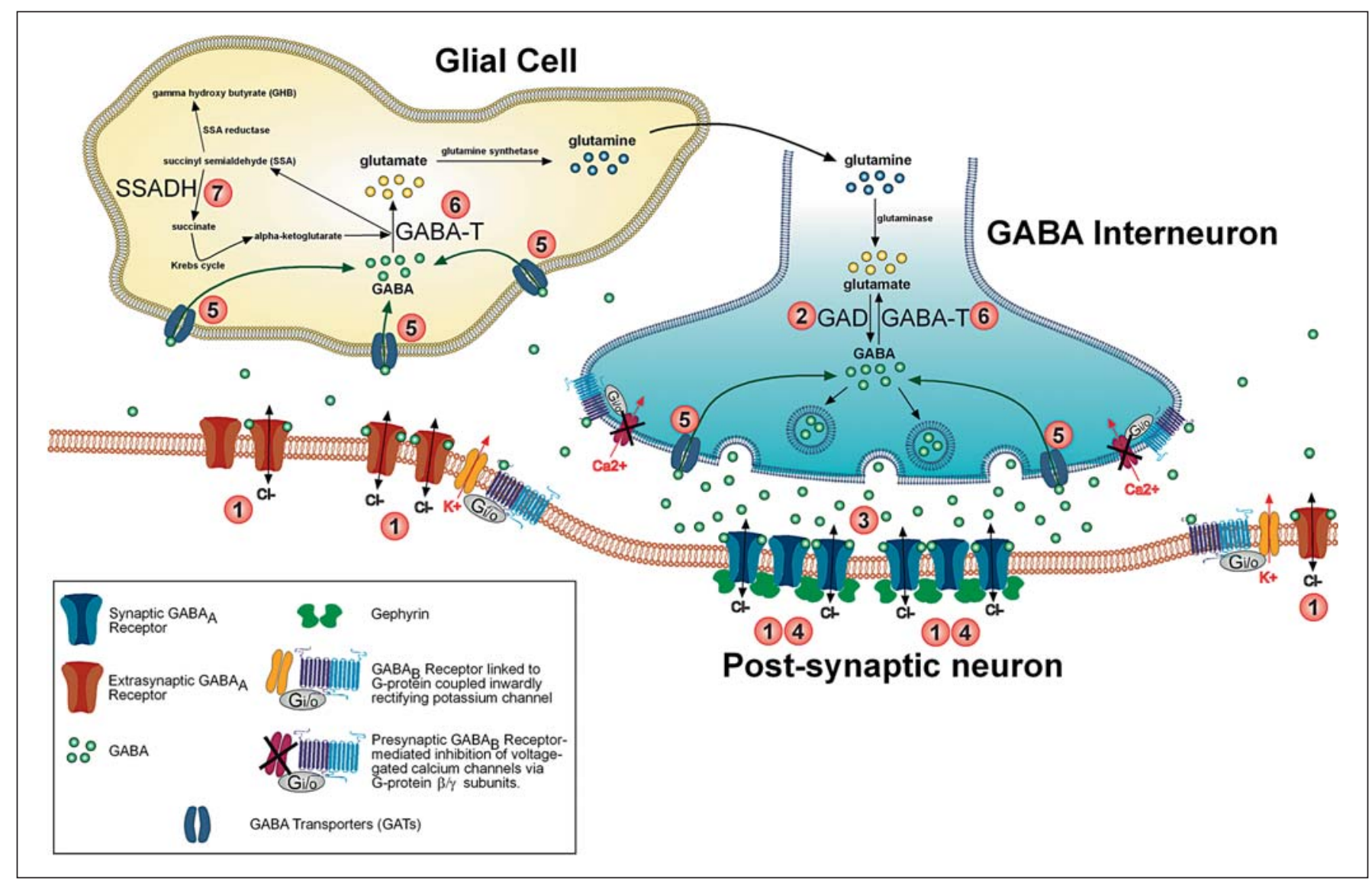

Fig. 1. Several GABAergic synapse components exhibit altered expression in the Fmr1 KO mouse model of FXS. Numbers identify key synaptic proteins disrupted in Fmrl KOs, including GABA receptors, enzymes involved in GABA production and catabolism (GAD, SSADH, GABA-T) and GAT (inset legend; table 1).

studies of mRNA expression in the brains of Fmrl KO mice revealed prominent reductions in the expression of $\delta$, as well as $\alpha, \beta$, and $\gamma$ subunits in behaviorally relevant brain regions such as cortex and hippocampus [D'Hulst et al., 2006; Gantois et al., 2006]. Complementing these changes in receptor mRNA expression, decreases in $\alpha_{1}$, $\alpha_{5}, \beta$, and $\delta$ subunit protein expression [Adusei et al., 2010; Curia et al., 2008; El Idrissi et al., 2005] have been reported, as well as a reduction in gephyrin mRNA [D'Hulst et al., 2009], providing molecular evidence for alterations in inhibitory postsynaptic function in the FXS brain. On the presynaptic side, where FMRP is also expressed [Christie et al., 2009], both increases and decreases in the expression of the rate-limiting GABA-synthesizing enzyme GAD have been reported in Fmrl KOs [Adusei et al., 2010; D'Hulst et al., 2009; El Idrissi et al., 2005; Olmos-Serrano et al., 2010], with the nature of the change relying, at least in part, on the brain region examined (for example, Olmos-Serrano et al. [2010] report a pronounced decrease in GAD65/67 protein expression in the basolateral amygdala, complemented by decreased vesicular GABA levels, whereas El Idrissi et al. [2005] describe increased GAD65/67 in the cortex, hippocampus, brainstem, and diencephalon, in conjunction with reduced $\beta$ subunit expression). In addition, proteins required for GABA transport (GAT) and catabolism (GABA-T, SSADH) also exhibit decreased expression in a number of regions [Adusei et al., 2010; D'Hulst et al., 2009; Liao et al., 2008].

Taken together, the general picture provided by these studies is one of extensive dampening of the GABAergic system in FXS, wherein prominent changes in postsynaptic $\mathrm{GABA}_{\mathrm{A}}$ receptor expression act in combination with alterations in GABA production, metabolism, and release to significantly modify GABAergic function in FXS (fig. 1; table 1). 
Table 1. GABAergic synapse components with altered expression in Fmr1 KO mice

\begin{tabular}{|c|c|c|c|c|c|}
\hline 1 & $\begin{array}{l}\mathrm{GABA}_{\mathrm{A}} \text { receptor } \\
\text { subunits }(\alpha, \beta, \gamma, \delta)\end{array}$ & $\begin{array}{l}\text { Ionotropic GABA receptor } \\
\text { function, localization }\end{array}$ & $\begin{array}{l}\text { Cortex, subiculum, } \\
\text { hippocampus }\end{array}$ & $\downarrow$ mRNA, protein & $\begin{array}{l}\text { El Idrissi et al., 2005; } \\
\text { D’Hulst et al., 2006; } \\
\text { Gantois et al., 2006; } \\
\text { Curia et al., 2008; } \\
\text { Adusei et al., } 2010\end{array}$ \\
\hline 3 & GABA & Ligand & Amygdala & $\downarrow$ release & Olmos-Serrano et al., 2010 \\
\hline 4 & Gephyrin & GABA receptor clustering & Cortex & $\downarrow$ mRNA & D’Hulst et al., 2009 \\
\hline 6 & GABA-T & GABA catabolism & Cortex & $\downarrow$ mRNA, protein & $\begin{array}{l}\text { D’Hulst et al., 2009; } \\
\text { Adusei et al., } 2010\end{array}$ \\
\hline 7 & SSADH & GABA catabolism & Cortex, cerebellum & $\downarrow$ mRNA, protein & $\begin{array}{l}\text { D’Hulst et al., 2009; } \\
\text { Adusei et al., } 2010\end{array}$ \\
\hline
\end{tabular}

\section{Inhibitory Deficits in Fmr1 KO Mice Are Pervasive, but Region-Specific}

Alongside extensive changes in the expression of crucial components of the GABAergic system, Fmrl KO mice exhibit broad, variable, and distinct disruptions in functional inhibitory transmission in a number of behaviorally relevant brain regions. These observed alterations are highly region-specific, in accordance with the unique function and circuit properties of these individual structures (fig. 2).

One region of the brain of particular relevance for the behavioral phenotype of FXS is the amygdala, a limbic structure involved in the processing of emotionally salient information and in the acquisition, storage, and extinction of fear memories [Ehrlich et al., 2009; Ledoux, 2003]. The processing of this complex information within this structure relies heavily on inhibitory circuit function [Ehrlich et al., 2009]. In line with evidence of amygdala dysfunction in FXS patients and mouse models alike [Budimirovic et al., 2006; Hagerman et al., 2009; McNaughton et al., 2008; Paradee et al., 1999], the basolateral amygdala of Fmr1 KO mice is characterized by broad and severe inhibitory defects, including reductions in the frequency and amplitude of spontaneous and miniature inhibitory postsynaptic currents (IPSCs), changes in IPSC kinetics, decreased GAD expression and vesicular GABA, and impaired GABA release [Olmos-Serrano et al., 2010]. These alterations in synaptic function are accompanied by a reduction in inhibitory synapse number, indicating aberrant circuit development. In addition to severe deficits in fast synaptic phasic inhibition, Fmr1 KOs also exhibit a profound reduction in tonic inhibition, a major form of GABAergic inhibition in the CNS that relies on GABA availability (determined in part by GABA synthesis, release, uptake, and metabolism), as well as the expression of perisynaptic and extrasynaptic $\mathrm{GABA}_{\mathrm{A}}$ receptors containing subunits with a high affinity for GABA, such as $\delta$ and $\alpha_{5}$ [Farrant and Nusser, 2005; Semyanov et al., 2004].

The strong, persistent inhibitory conductance provided by tonic inhibition acts to reduce membrane excitability, and thus is an important determinant of cellular output [Semyanov et al., 2004], as illustrated by the occurrence of hippocampal CA3 region hyperexcitability in $\mathrm{GABA}_{\mathrm{A}}$ receptor $\alpha_{5}$ subunit KO mice, for example [Glykys and Mody, 2006]. Given the evidence for altered GABA levels and reduced expression of $\delta$ and $\alpha_{5} \mathrm{GABA}_{\mathrm{A}}$ receptor subunits in Fmrl KOs, tonic inhibition is expected to be broadly compromised in the FXS brain. In agreement 


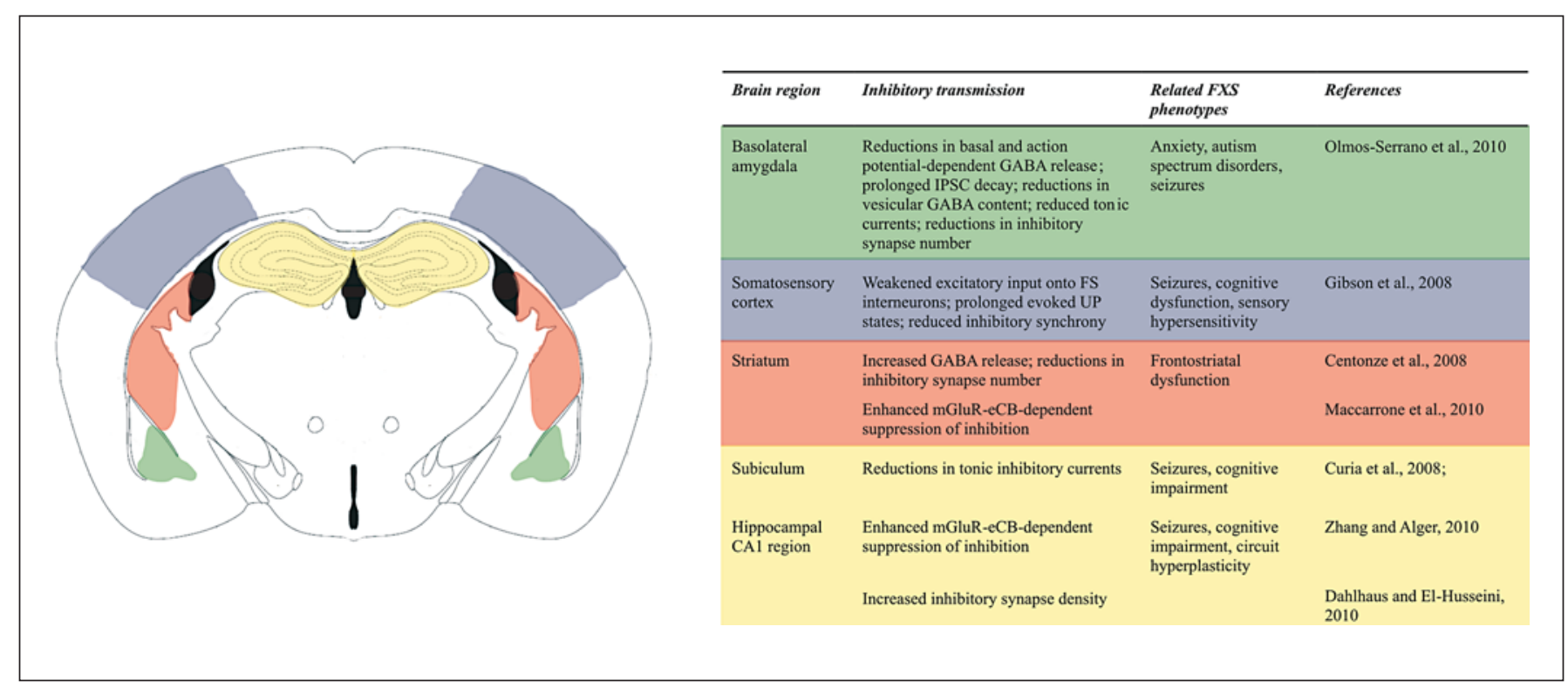

Fig. 2. Alterations in inhibitory neurotransmission in the Fmrl KO mouse brain are pervasive, but region-specific. Regional inhibitory deficits are associated with a number of common FXS phenotypes (inset table). Affected regions include the basolateral amygdala, cerebral cortex, striatum and hippocampus/subiculum. Color coding in the illustration corresponds to the adjacent inset table.

with the findings in the amygdala, recordings from subicular neurons in Fmrl KOs also reveal a prominent decrease in tonic inhibition, concurrent with regional reduction in $\delta$ and $\alpha_{5}$ mRNA and protein expression [Curia et al., 2008]. In contrast to the amygdala, however, synaptic inhibition is unaltered, indicating circuit-specific effects of FMRP deletion. Broadly speaking, these studies in the amygdala and the subiculum reveal that dampened inhibitory transmission may indeed be a hallmark of the FXS brain. This, however, does not appear to be the case in all brain regions. A recent study of striatal neurons in Fmr1 KO mice demonstrates an increase in basal inhibitory transmission driven by increased GABA release [Centonze et al., 2008]. This unique alteration is suggested to contribute to the frontostriatal dysfunction that is frequently observed in FXS patients [Hoeft et al., 2007; Menon et al., 2004], and may be involved in FXS-associated phenotypes such as attention deficit hyperactivity disorder and repetitive behaviors [Reiss et al., 1995]. As further evidence of the bidirectional nature of inhibitory alterations in Fmrl KOs, recent evidence suggests increased numbers of inhibitory synapses in the CA1 region of the hippocampus [Dahlhaus and El-Husseini, 2010].

Together, studies in the amygdala, striatum, and subiculum reveal specific alterations in inhibitory transmis- sion in Fmr1 KO mice, with those in the first two regions identifying clear presynaptic abnormalities and thus implicating dysfunction of presynaptic inhibitory interneurons as a key component of circuit defects. It is important to keep in mind, however, that normal inhibitory circuit function not only requires that interneurons form appropriate synaptic contacts onto their targets, as well as synthesize, release, and metabolize GABA in a dynamic way, but also that they receive appropriate excitatory input and respond normally to network activity. A study of parvalbumin-expressing fast-spiking (FS) interneurons in primary somatosensory (barrel) cortex and their integration with regular-spiking (RS) excitatory neurons reveals normal FS to RS transmission in Fmrl KOs, but deficits in RS to FS transmission [Gibson et al., 2008]. This was found to be accompanied by an increase in the duration of stimulus-induced coordinated increases in network activity (UP states), as well as a decrease in gamma-frequency synchronization, illustrating important downstream effects of impaired activity-dependent interneuron activation at the cortical circuit level. These inhibitory circuit defects in Fmrl KOs provide evidence in line with common FXS phenotypes such as cognitive impairment, sensory hypersensitivity, epilepsy, and abnormal cortical EEG patterns [Berry-Kravis, 2002; Berry-Kravis et al., 2010; Hagerman 
and Stafstrom, 2009; Miller et al., 1999; Musumeci et al., 1988, 1999] that likewise suggest excitatory/inhibitory imbalances in the cerebral cortex.

In addition to these alterations in basic inhibitory neurotransmission, two recent studies implicate aberrant modulation of transmission in the pathogenesis of FXS. GABA release is modulated by signaling through a number of presynaptic receptors, including the $\mathrm{GABA}_{\mathrm{B}}$ and cannabinoid receptors, which act to reduce GABA release [Bacci et al., 2005; Misgeld et al., 1995; Wilson and Nicoll, 2002]. In the CA1 region of the hippocampus, there is enhanced coupling of group I metabotropic glutamate receptor (mGluR) signaling and endocannabinoid (eCB) mobilization in Fmr1 KOs, which results in enhanced suppression of inhibitory transmission [Zhang and Alger, 2010]. This increase in the suppression of inhibition is proposed as a potential contributor to the enhanced mGluR-dependent synaptic plasticity previously observed in the Fmr1 KO hippocampus [Huber et al., 2002] and cognitive impairment in FXS. This finding not only suggests a link between excessive group I mGluR signaling and hyperplasticity of excitatory synapses in FXS, but also between mGluRs and alterations in inhibitory function, an important consideration, given that group I mGluRs are differentially expressed in a number of inhibitory neuron subtypes [Kerner et al., 1997; Stinehelfer et al., 2000; Sun et al., 2009]. Interestingly, excessive group I mGluR-eCB-dependent suppression of inhibition has also been observed in the striatum [Maccarrone et al., 2010], indicating that disruption of this signaling pathway may be disrupting inhibitory transmission in other brain regions as well.

It is not yet known whether other signaling pathways affecting GABA release, such as presynaptic $\mathrm{GABA}_{\mathrm{B}}$ receptor-mediated transmission, are similarly enhanced or disrupted in Fmr1 KOs. Given the evidence for altered GABAergic transmission and presynaptic function in a number of brain regions, the presynaptic $\mathrm{GABA}_{\mathrm{B}}$ receptors present an intriguing candidate for future studies.

Together, these findings from different key brain regions demonstrate that perturbations of inhibitory transmission are a hallmark of FMRP loss. These changes have distinct implications for the balance of excitation and inhibition, and thus, network function and behavioral output. In some ways, these inhibitory defects can be viewed as an 'end result' of disrupted circuit development. Little is known, however, about how these significant alterations arise over the course of brain development. Interneuron development and the formation and refinement of precise inhibitory circuits are highly complex and still incompletely understood. Nevertheless, it is within the framework of these processes that the inhibitory deficits observed in FXS patients and Fmrl KO mice are presumed to arise. An understanding of the developmental timeline of the GABAergic system is therefore required in order to gain insight into the developmental mechanism of any neurodevelopmental disorder involving synaptic and circuit dysfunction. In the following section, we provide a brief outline of the role of GABA in development and the timeline of inhibitory circuit formation. We discuss how the observed molecular changes in the GABAergic system might drive alterations in mature neurotransmission, and vice versa. In doing so, we identify developmental processes that might be perturbed in the FXS brain.

\section{GABA in the Development of Functional Neural Circuits}

The development of functional inhibitory circuitry is a complex and prolonged process, extending from embryonic stages well into the postnatal period, that relies on a number of intrinsic and extrinsic factors, including gene expression, cell location, and exposure to neurotransmitters and neurotrophins [Batista-Brito and Fishell, 2009; Wang and Kriegstein, 2009]. The importance of FMRP for normal circuit development is illustrated by the fact that Fmrl KO mice exhibit a number of defects suggestive of aberrant or delayed development, including disruptions in synaptic plasticity [Desai et al., 2006; Huber et al., 2002; Li et al., 2002; Suvrathan et al., 2010; Wilson and Cox, 2007], early, transient defects in cortical excitatory connectivity and cell morphology [Bureau et al., 2008], delayed timing of critical period plasticity [Harlow et al., 2010], increased cellular excitability [Chuang et al., 2005], and elevated numbers of immature dendritic spines [Comery et al., 1997; Galvez et al., 2003; Irwin et al., 2001].

The prevalence of inhibitory dysfunction in a neurodevelopmental disorder like FXS prompts an important question: do early GABAergic defects contribute to abnormal circuit development, or do these defects arise as a result of the influences of an abnormally developing circuit? The short answer to this question is that given the current data, we cannot be sure. The expression of FMRP begins at early embryonic stages in the mouse brain and persists throughout development and into adulthood [Bakker et al., 2000; Hinds et al., 1993; Wang et al., 2004]. A similar expression profile is observed in humans, with 
Fmrl and FMRP detectable in the brain at the embryonic, fetal, and adult stages [Abitbol et al., 1993; Agulhon et al., 1999; Tamanini et al., 1997]. FMRP is therefore temporally well-positioned to regulate key steps of inhibitory circuit development, which include migration and fate specification, morphological development and formation of initial synaptic contacts, and synaptic refinement and circuit maturation. GABA signaling has a crucial role in all of these processes [Ben-Ari, 2002; Wang and Kriegstein, 2009], and given that normal GABAergic system function depends on the presence of FMRP, it is likely that GABAergic dysfunction during development contributes to mature circuit alterations in FXS. Analysis of forebrain expression of GABAergic synapse proteins in Fmrl KO mice suggests a system that is at least partially compromised as early as P5 [Adusei et al., 2010]. Furthermore, the inhibitory circuit defects observed in the somatosensory cortex were observed as early as postnatal week 2 [Gibson et al., 2008]. Together, these are indicative of the presence of functional inhibitory deficits during key times in inhibitory circuit development. In light of this evidence for early depression of the GABAergic system, we focus this section on the known roles of GABAergic signaling in development.

In mature neurons, GABA's action through $\mathrm{GABA}_{\mathrm{A}}$ receptors is inhibitory. Intracellular $\mathrm{Cl}^{-}$levels are low, and thus, upon channel opening, $\mathrm{Cl}^{-}$ions enter the cell, hyperpolarizing the membrane and reducing cellular excitability. During embryonic and early postnatal development, however, GABA is depolarizing and thus excitatory [Ben-Ari, 2002], due to a high intracellular $\mathrm{Cl}^{-}$concentration, maintained by the $\mathrm{Na}^{+} / \mathrm{K}^{+} / \mathrm{Cl}^{-}$co-transporter NKCC1 [Yamada et al., 2004]. Before the emergence of functional synapses in the brain, the depolarizing action of GABA exerts prominent effects on neuronal development, regulating the proliferation of neuronal progenitors [Haydar et al., 2000; LoTurco et al., 1995], as well as providing both permissive and stop signals for neuronal migration via $\mathrm{GABA}_{\mathrm{A}}$ and $\mathrm{GABA}_{\mathrm{B}}$ receptor signaling [Behar et al., 1998, 2000, 2001; López-Bendito et al., 2003; Manent et al., 2005]. GABAergic signaling, therefore, is an important determinant of early neuronal development, helping to set the stage for circuit formation. Interestingly, FXS patients exhibit structural alterations in a number of brain regions, including the caudate nucleus, amygdala, and hippocampus [Gothelf et al., 2008; Reiss et al., 1994], indicating that perturbations of proliferation and migration may indeed occur in the absence of FMRP. This issue remains largely unexplored in Fmrl KO mice, however. Studies reveal no alterations in the gross mor-

GABAergic and Circuit Dysfunction in FXS phology or in cell number in the basolateral amygdala of Fmrl KOs at P21, and even more specifically, no changes in the number of GABA-expressing cells [Olmos-Serrano et al., 2010]. A study of adult Fmr1 KO mice, however, reveals slight changes in the distribution and density of PVpositive cells in primary somatosensory cortex [Selby et al., 2007], illustrating that specific neuronal populations might be sensitive to proliferative or migrational defects in FXS.

Provided that GABAergic neurons arrive at the correct locations, they are well-positioned to guide early circuit formation and maturation, first through the continued depolarizing action of GABA, then later through its inhibitory hyperpolarizing action. In the rodent hippocampus, functional GABAergic synapses are present on both pyramidal neurons and interneurons at birth, and are established before functional glutamatergic synapses [Hennou et al., 2002; Tyzio et al., 1999]. At this stage, GABA is still depolarizing, and acts through $\mathrm{GABA}_{\mathrm{A}}$ receptors to increase $\mathrm{Ca}^{2+}$ influx through NMDA receptors and promote glutamatergic synapse maturation [Akerman and Cline, 2006; Wang and Kriegstein, 2008]. In the absence of GABA's early depolarizing action, these key processes are disrupted and result in imbalances in excitatory and inhibitory transmission and disrupted dendritic maturation [Akerman and Cline, 2006; Wang and Kriegstein, 2008]. Thus, GABA signaling is required at even the earliest stages of functional circuit maturation. As noted above, the Fmrl KO brain exhibits abnormalities in glutamatergic synaptic function, including enhanced NMDA/AMPA ratios at early postnatal ages [Harlow et al., 2010] that may reflect developmental delays in synaptic maturation. It is not yet clear how GABAergic defects might contribute to alterations in glutamatergic synaptic function in FXS, but they provide an intriguing mechanistic candidate.

Inhibitory synaptogenesis is characterized by a period of rapid increase in synapse number and maturation that terminates around the end of the 4th postnatal week [De Felipe et al., 1997; Micheva and Beaulieu, 1996]. Not surprisingly, this process is also driven by GABAergic signaling. In the absence of neuronal activity or the ratelimiting GABA-synthesizing enzyme GAD67, inhibitory synaptogenesis is profoundly reduced [Chattopadhyaya et al., 2004, 2007]. Interestingly, inhibitory synaptogenesis can also be driven with $\mathrm{GABA}_{\mathrm{A}}$ and $\mathrm{GABA}_{\mathrm{B}}$ receptor agonists [Chattopadhyaya et al., 2007], illustrating a strong link between presynaptic activity, GABA production/release, and synaptic maturation. These observations in the mouse neocortex are intriguing in light of the 
findings that both GAD levels and inhibitory synapse numbers are disrupted in multiple brain regions of Fmr1 $\mathrm{KO}$ mice. In the context of the basolateral amygdala, which exhibits significant reductions in both of these measures in Fmrl KO mice during the 4th postnatal week (see above), one clear hypothesis would be that blunted GAD levels - and therefore reduced GABA release and receptor activation - could be occurring early in development and causing reductions in inhibitory synaptic innervation of excitatory cells. In contrast, increased GABAergic synapse numbers [Dahlhaus and El-Hussei$\mathrm{ni}, 2010$ ], as well as increased GAD levels [El Idrissi et al., 2005] are reported in the hippocampus, suggesting that early misregulation of GABA production might drive region-specific alterations in mature inhibitory function. The developmental timeline of GAD expression (GAD67 in particular) in Fmrl KOs remains to be determined, but could provide a useful link between molecular and functional circuit alterations.

Studies in rodents and nonhuman primates indicate that the expression of $\mathrm{GABA}_{\mathrm{A}}$ receptor subunits is developmentally regulated in accordance with GABAergic synapse maturation [Fritschy et al., 1994; Golshani et al., 1997; Huntsman et al., 1999; Laurie et al., 1992]. This maturation generally involves the upregulation of subunits mediating 'fast' $\mathrm{GABA}_{\mathrm{A}}$ responses (fast IPSC decay kinetics) such as $\alpha_{1}$, and the concurrent downregulation of 'slow' subunits, such as $\alpha_{3}$ [Bosman et al., 2002; Dunning et al., 1999; Heinen et al., 2004; Hollrigel and Soltesz, 1997; Huntsman and Huguenard, 2000; Vicini et al., 2001], and thus comprises an important developmental 'switch'. Notably, this subunit switching occurs alongside synaptogenesis [De Felipe et al., 1997] and the maturation of GABAergic transmission from excitatory to inhibitory, which similarly depends on a developmental switch - the upregulation of the $\mathrm{Cl}^{-}$-extruding $\mathrm{K}^{+} / \mathrm{Cl}^{-}$co-transporter KCC2 [Rivera et al., 1999; Wang et al., 2002]. The temporal coincidence of these processes indicates that they are all likely to be mechanistically related. Indeed, changes in IPSC decay mediated by the increase in synaptic $\alpha_{1}$ subunits are accompanied by changes in IPSC frequency and amplitude, as well as presynaptic release probability [Huntsman et al., 1999; Kirischuk et al., 2005; Kobayashi et al., 2008]. This presynaptic maturation is altered in $\alpha_{1}$ KO mice [Bosman et al., 2005; Ortinski et al., 2004], illustrating the requirement for correct postsynaptic receptor composition for synaptic maturation. In addition, inhibitory synapse stability has been shown to depend on $\mathrm{GABA}_{\mathrm{A}}$ receptor clustering by the scaffolding protein gephyrin [Fritschy and Brunig, 2003; Li et al., 2005; Yu et al., 2007], as well as by neuroligin-2 (NL-2)-neurexin interactions [Chih et al., 2005; Chubykin et al., 2007; Gibson et al., 2009; Hines et al., 2008; Poulopoulos et al., 2009; Varoqueaux et al., 2004]. Interestingly, FMRP can associate with NL-2 mRNA and influence expression of the NL-2 protein [Dahlhaus and El-Husseini, 2010], and genetic manipulation of NL-2 levels in mice leads to imbalances in excitatory and inhibitory transmission, anxiety-related behaviors, stereotypies, and abnormal social behaviors consistent with models of ASD and FXS [Blundell et al., 2009; Hines et al., 2008; Moy et al., 2009], an intriguing finding given the known associations of other neuroligin isoforms with ASD [Südhof, 2008].

An important consideration when investigating neuronal and circuit function in Fmrl KOs is that, of the numerous GABAergic synapse components with altered expression, direct binding has only been shown for the $\mathrm{GABA}_{\mathrm{A}}$ receptor $\delta$ subunit. The changes in the expression of other receptor subunits or GAD, for example, might therefore arise not due to a loss of their direct interactions with FMRP, but instead could reflect secondary effects of altered mRNA stability [De Rubeis and Bagni, 2010] or changes in intercellular communication resulting from translational misregulation of other FMRP-binding mRNAs. Alternatively, these widespread changes in the GABAergic system could constitute compensatory changes in response to abnormalities in the developing circuit, such as an altered balance of excitation and inhibition. As an example, reductions in inhibitory synapse number in the striatum are proposed to arise in order to offset an increase in GABA release [Centonze et al., 2008]. Along the same lines, increases in IPSC decay kinetics in the basolateral amygdala [Olmos-Serrano et al., 2010] might reflect a homeostatic upregulation of 'slow' $\mathrm{GABA}_{\mathrm{A}}$ receptor subunits in response to reductions in inhibitory input, with increased IPSC duration acting to compensate for decreases in IPSC amplitude and frequency. Homeostatic changes in synaptic inhibition are frequently observed in sensory cortex in response to changes in circuit activity [Li et al., 2009; Maffei and Turrigiano, 2008; Maffei et al., 2006; Micheva and Beaulieu, 1995] and represent an important form of network plasticity that is likely to emerge in a number of neurodevelopmental disorders.

Currently, it is not entirely clear whether the circuit deficits observed in Fmrl KOs represent developmental delay, homeostasis, or a wholly aberrant circuit. It is clear, however, that the potential developmental implications of a dysfunctional GABAergic system are numerous and complex. At the moment, detailed developmental studies 
Table 2. Potential FXS treatments targeting deficits in the GABAergic system

\begin{tabular}{|c|c|c|c|c|c|c|}
\hline & Compound & Target & Effect & \multicolumn{2}{|c|}{ FDA approval } & \multirow{2}{*}{$\begin{array}{l}\text { References } \\
\text { Reddy, 2010; } \\
\text { Biagini et al., } 2010\end{array}$} \\
\hline 1 & Ganaxolone & $\begin{array}{l}\text { GABA receptors, synaptic } \\
\text { and extrasynaptic }\end{array}$ & $\begin{array}{l}\text { potentiates/activates } \mathrm{GABA}_{\mathrm{A}} \\
\text { transmission }\end{array}$ & No & $\begin{array}{l}\text { Phase II clinical trials: infantile spasms, } \\
\text { complex partial and catamenial epilepsy }\end{array}$ & \\
\hline 4 & Arbaclofen & $\mathrm{GABA}_{\mathrm{B}}$ receptors & Activates $\mathrm{GABA}_{B}$ transmission & No & $\begin{array}{l}\text { Phase II clinical trials: FXS, autism spectrum } \\
\text { disorders }\end{array}$ & Pacey et al., 2009 \\
\hline
\end{tabular}

of the GABAergic system in Fmr1 KOs are largely lacking, and studies, for example of $\mathrm{GABA}_{\mathrm{A}}$ receptor function given the pronounced disruptions in expression, would be highly informative in this respect. Still, it is important to keep in mind that normal circuit development requires the actions of several dynamic intrinsic and extrinsic factors, many of which are likely contributors to the pathogenesis of FXS, including, for example, neurotrophic factors. Given that there is currently little data regarding these factors in the FXS brain, we have not focused on this issue. It is noteworthy, however, that semaphorin $3 \mathrm{~F}$, which can act as a chemorepellent, guide the migration [Marín et al., 2001; Tamamaki et al., 2003] and axon outgrowth [Pascual et al., 2005] of GABAergic interneurons, has been identified as a binding partner of FMRP [Darnell et al., 2001].

\section{GABAergic System Components as Potential Therapeutic Targets for FXS}

To date, a primary therapeutic target in FXS has been the metabotropic glutamate receptor 5 (mGluR5), based on evidence of unregulated signaling downstream of this receptor in Fmrl KO mice [Chuang et al., 2005; Dolen and Bear, 2008; Jacquemont et al., 2011; Yan et al., 2005]. Given the increasingly understood prevalence of inhibitory dysfunction in FXS, however, the GABAergic system also presents a number of relevant and intriguing targets for treatment that are distinct from therapeutics aimed at reducing mGluR signaling. As described above, current evidence generally reveals an extensive dampening of GABAergic function throughout the adult FXS brain, and this dysfunction has been implicated in many of the hallmark symptoms of FXS, including anxiety, autistic behaviors, epilepsy, and cognitive impairment. GABAergic compounds, in turn, have demonstrated therapeutic efficacy in many of these disorders. Therefore, compounds targeting the GABAergic system may provide novel, effective, and in some cases, currently available treatment options for the symptoms of FXS (fig. 3; table 2).

The first study that systematically identified GABAergic components as possible targets for FXS treatment used the Fmr1 KO Drosophila melanogaster model of FXS to screen 2,000 compounds for their ability to rescue glutamate-induced toxicity in developing fly larvae related to hypertrophic mGluR signaling [Chang et al., 2008]. Of the 9 compounds identified in this screen, 3 acted on the GABAergic system: nipecotic acid (a GAT blocker), creatinine (a $\mathrm{GABA}_{\mathrm{A}}$ receptor activator), and GABA itself. Not only did these compounds rescue glutamate-induced lethality, but they also rescued characteristic cellular, morphological, and behavioral phenotypes related to FXS in the adult Fmrl KO flies. Therefore, compounds that increase the function of the GABAergic system, either by increasing the availability of GABA (nipecotic acid) or acting directly at GABA receptors (creatinine and GABA), can rescue FXS phenotypes.

Two clinically available, FDA-approved anticonvulsants function like nipecotic acid to increase the avail- 


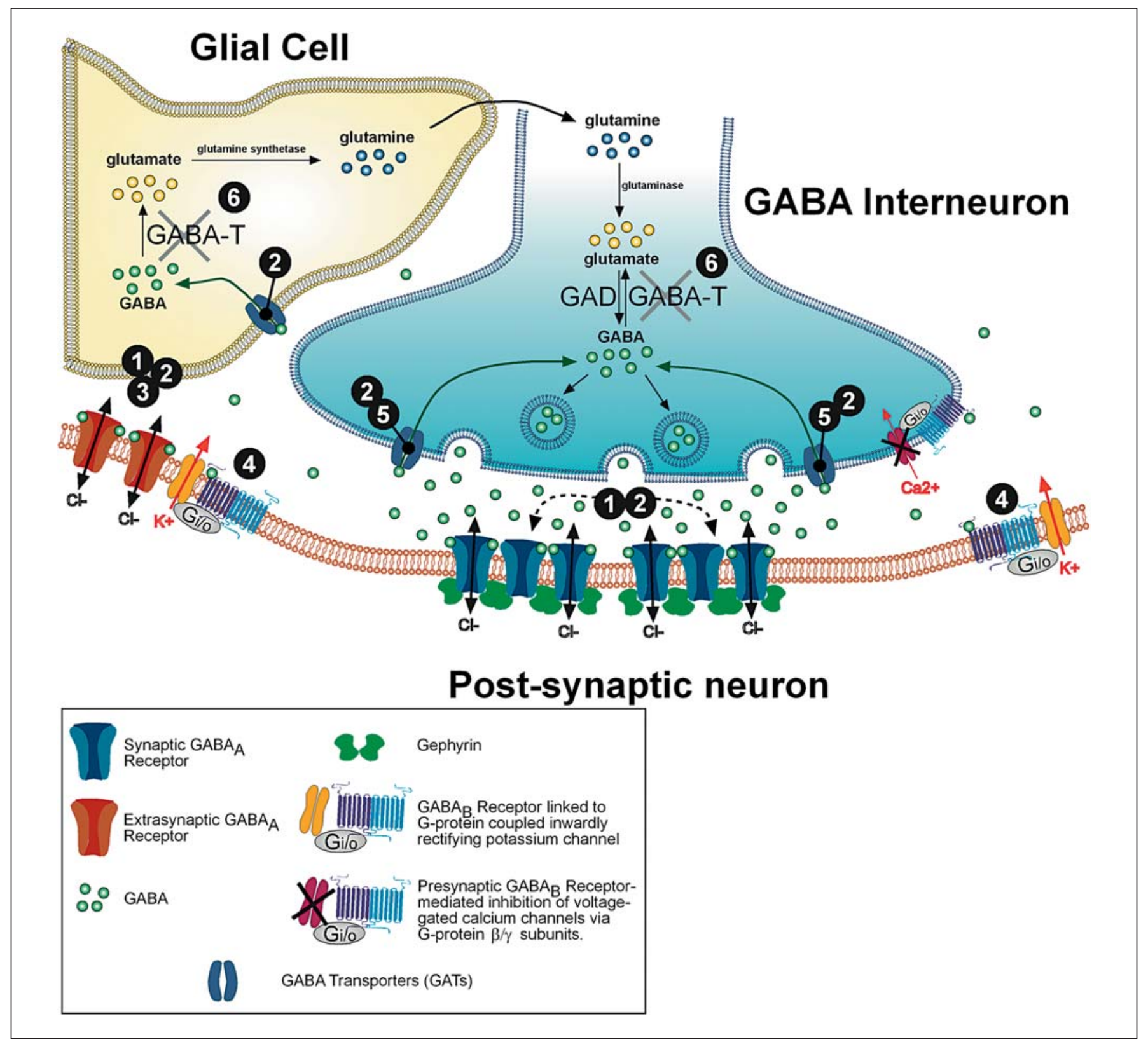

Fig. 3. Potential pharmacological targets for the treatment of FXS. Numbers identify loci of action of pharmacological compounds targeting components of the GABAergic system (inset legend; table 2). Note: The presumed actions of arbaclofen (4) are illustrated as predominately postsynaptic, since presynaptic modulation is expected to reduce GABA release via a reduction in voltage-dependent calcium influx. However, since glutamatergic terminals also express presynaptic $\mathrm{GABA}_{\mathrm{B}}$ receptors, additional beneficial actions of arbaclofen could also lie in the reduction of glutamate release from excitatory synapses. ability of GABA and therefore could show efficacy in FXS. The first, tiagabine, specifically blocks the presynaptic GABA transporter 1 (GAT1), thus increasing synaptic GABA levels and enhancing phasic and tonic GABAergic inhibition [Nielsen et al., 1991]. The second, vigabatrin, blocks the catabolism of GABA by inhibiting the function of GABA transaminase (GABA-T), which is required for the breakdown of GABA to glutamate. This blockade increases GABA availability, both intracellularly, for packaging into presynaptic vesicles, and extracel- 
lularly [Chiron et al., 1997; French et al., 1996]. Although these compounds exhibit efficacy at improving GABAergic function, they do not work in all patients and have a high incidence of side effects, including retinal neuropathy [Frisén and Malmgren, 2003]. Their GABAergic actions, however, may warrant investigation in FXS.

Many compounds act directly on $\mathrm{GABA}_{\mathrm{A}}$ receptors, and therefore may also improve symptoms of FXS. For instance, the free amino acid taurine acts as an agonist at $\mathrm{GABA}_{\mathrm{A}}$ receptors, increases GAD expression, increases GABA levels, induces changes in $\mathrm{GABA}_{\mathrm{A}}$ receptor subunit composition [L'A moreaux et al., 2010], and decreases seizure susceptibility [El Idrissi and L'Amoreaux, 2008]. This endogenous amino acid is developmentally dysregulated in Fmrl KO mice [Gruss and Braun, 2004], and chronic taurine feeding improves cognition [El Idrissi et al., 2009] and neuroendocrine symptoms in these animals [El Idrissi et al., 2010].

Several other compounds that potentiate $\mathrm{GABA}_{\mathrm{A}}$ receptor function have been identified and/or examined in preclinical and clinical trials for FXS or its related symptoms. One compound, riluzole, has multiple modes of action to decrease excitability, including $\mathrm{GABA}_{\mathrm{A}}$ receptor potentiation [Jahn et al., 2008] and GAT blockade [Mantz et al., 1994]. Riluzole is an FDA-approved anticonvulsant often utilized for amyotrophic lateral sclerosis treatment in adults and in one preclinical trial shows mild efficacy in improving attention deficit disorder with hyperactivity in adult FXS patients [Erickson et al., 2010]. Another compound, gaboxadol, acts preferentially at extrasynaptic, tonic $\delta$-subunit-containing $\mathrm{GABA}_{\mathrm{A}}$ receptors to dampen cellular excitability via increased tonic inhibitory conductance [Brown et al., 2002; Glykys and Mody, 2007]. This compound, previously used as a sleep aid [Deacon et al., 2007; Lundahl et al., 2007], rescues the hyperexcitability of principal output excitatory neurons in the basolateral amygdala of Fmrl KO mice [Olmos-Serrano et al., 2010], clearly demonstrating its potential therapeutic benefit in FXS patients, particularly with respect to amygdala-based behaviors, such as anxiety and features of ASD.

Benzodiazepines are proven, effective $\mathrm{GABA}_{\mathrm{A}}$ receptor agonists, but often present unwanted side effects, including sedation and rebound symptoms such as anxiety when treatment is discontinued [Nemeroff, 2003], and therefore might not be the optimal agents to treat symptoms of FXS. Interestingly, another class of molecules, the neurosteroids, increase GABAergic receptor function via positive allosteric modulation [Belelli and Lambert, 2005]. Natural neurosteroids such as allopregnanolone are not orally active, but one new synthetic neurosteroid, ganaxo-

GABAergic and Circuit Dysfunction in FXS lone, the $3 \beta$-methyl analogue of allopregnanolone, is orally active, lacks hormonal side effects, and has entered phase II clinical trials for infantile spasms, partial seizures, and catamenial epilepsy [Reddy, 2010]. A neuroactive steroid like ganaxolone may be useful in the treatment of anxiety and seizures associated with FXS, and has advantages over benzodiazepines, given the low occurrence of side effects and evidence of preferential effects at extrasynaptic, tonically active $\delta$-subunit-containing receptors [Biagini et al., 2010; Mihalek et al., 1999; Reddy, 2010].

Finally, GABAergic function can also be enhanced via the activation of postsynaptic $\mathrm{GABA}_{\mathrm{B}}$ receptors, and stimulation of these receptors has shown promise as a treatment in animal models of FXS. Although no published data describes postsynaptic $\mathrm{GABA}_{\mathrm{B}}$ currents in Fmrl KO mice, activation of these receptors with the agonist baclofen reduces audiogenic seizure susceptibility in these animals [Pacey et al., 2009]. Accordingly, phase II clinical trials for safety and efficacy of the most active isomer of baclofen, arbaclofen, are currently being conducted in FXS patients (clinicaltrials.gov). The use of $\mathrm{GABA}_{\mathrm{B}}$ receptor-targeting therapeutics, however, could be complicated by any actions on presynaptic receptors, which act to reduce GABA release (and thus decrease synaptic inhibition) via inhibition of voltage-gated $\mathrm{Ca}^{+}$ channels [Padgett and Slesinger, 2010].

\section{Concluding Remarks}

FXS is a pervasive neurodevelopmental disorder characterized by extensive synaptic and circuit dysfunction, and profound alterations in the GABAergic system are now emerging as major contributors to the hyperexcitable circuit phenotype. Studies in Fmr1 KO mice reveal disturbances of the GABAergic system and functional inhibitory neurotransmission in a number of brain regions that are highly relevant to the FXS phenotype, including the amygdala, cerebral cortex, hippocampus, and striatum. Thus, the GABAergic system presents an important pharmacological target for the treatment of a number of the neurological manifestations of FXS.

While GABAergic dysfunction has been implicated in a number of disease states involving synaptic and circuit dysfunction, the similarities between FXS and other developmental disorders are particularly intriguing. Rett syndrome, for example, is similarly characterized by intellectual disability and elevated incidences of ASD [Moretti and Zoghbi, 2006], and mouse models of Rett syndrome, like FXS models, exhibit prominent altera- 
tions in GABAergic function [Chao et al., 2010; Dani et al., 2005; Medrihan et al., 2008]. This parallel between FXS and Rett syndrome models suggests that GABAergic dysfunction may represent a common pathway to brain dysfunction in neurodevelopmental disorders.

The development and maturation of neural circuits relies on a series of highly precise and complex processes, and disturbances of these processes can drastically alter mature circuit function. GABAergic signaling is essential for correct neuronal migration, maturation, and circuit formation, and defects in the GABAergic system are therefore likely to have profound effects on neuronal development and circuit function in FXS. Currently, early developmental alterations in GABAergic function are not well understood in FXS, but an understanding of these should provide important insight into the nature of the FXS brain, as well as valuable information about key pharmacological targets. It is important to keep in mind, however, that the role of GABA in the developing CNS is dynamic and variable between brain regions (i.e. cortex, amygdala, striatum). Therefore, the same GABAergic effectors that aid adult patients could have adverse effects in developing individuals based on the role of GABA in particular brain regions at particular developmental time periods. In order to effectively utilize GABAergic targeting for FXS treatment, we must understand more about the role of GABA in specific brain regions during development of the FXS individual and develop specific treatments to affect region-specific circuit changes. Despite the challenges, further study of the GABAergic system will reveal crucial details of the developmental pathology of FXS as well as unique, targeted treatments for the disease.

\section{Acknowledgements}

This work was supported by NIH/NINDS (R01NS053719), Autism Speaks, and FRAXA grants to M.M.H., a CIHR doctoral research award to S.M.P., and an Epilepsy Foundation predoctoral training fellowship to B.S.M.

\section{References}

-Abitbol M, Menini C, Delezoide AL, Rhymer T, Vekemans M, Mallet J (1993): Nucleus basalis magnocellularis and hippocampus are the major sites of FMR-1 expression in the human fetal brain. Nat Genet 4:147-153.

-Adusei DC, Pacey LK, Chen D, Hampson DR (2010): Early developmental alterations in GABAergic protein expression in fragile $\mathrm{X}$ knockout mice. Neuropharmacology 59: 167-171.

-Agulhon C, Blanchet P, Kobetz A, Marchant D, Faucon N, Sarda P, Moraine C, Sittler A, Bianclana V, Malafosse A, Abitbol M (1999): Expression of FMR1, FXR1, and FXR2 genes in human prenatal tissues. J Neuropathol Exp Neurol 58:867-880.

-Akerman CJ, Cline HT (2006): Depolarizing GABAergic conductances regulate the balance of excitation to inhibition in the developing retinotectal circuit in vivo. J Neurosci 26:5117-5130.

Akerman CJ, Cline HT (2007): Refining the roles of GABAergic signaling during neural circuit formation. Trends Neurosci 30:382-389.

- Bacci A, Huguenard JR, Prince DA (2005): Modulation of neocortical interneurons: extrinsic influences and exercises in self-control. Trends Neurosci 28:602-610.

Bagni C, Greenough WT (2005): From mRNP trafficking to spine dysmorphogenesis: the roots of fragile X syndrome. Nat Rev Neurosci 6:376-387.

- Bakker CE, de Diego Otero Y, Bontekoe C, Raghoe P, Luteijn T, Hoogeveen AT, Oostra BA,
Willemsen R (2000): Immunocytochemical and biochemical characterization of FMRP, FXR1P, and FXR2P in the mouse. Exp Cell Res 258:162-170.

-Bassell GJ, Warren ST (2008): Fragile X syndrome: loss of local mRNA regulation alters synaptic development and function. Neuron 60:201-214

Batista-Brito R, Fishell G (2009): The developmental integration of cortical interneurons into a functional network. Curr Top Dev Biol 87:81-118.

- Behar TN, Schaffner AE, Scott CA, Greene CL, Barker JL (2000): GABA receptor antagonists modulate postmitotic cell migration in slice cultures of embryonic rat cortex. Cereb Cortex 10:899-909.

- Behar TN, Schaffner AE, Scott CA, O'Connell C, Barker JL (1998): Differential response of cortical plate and ventricular zone cells to GABA as a migration stimulus. J Neurosci 18:6378-6387.

Behar TN, Smith SV, Kennedy RT, McKenzie JM, Maric I, Barker JL (2001): GABA(B) receptors mediate motility signals for migrating embryonic cortical cells. Cereb Cortex 11: 744-753.

- Beierlein M, Gibson JR, Connors BW (2003): Two dynamically distinct inhibitory networks in layer 4 of the neocortex. J Neurophysiol 90:2987-3000.

-Belelli D, Lambert JJ (2005): Neurosteroids: endogenous regulators of the GABA(A) receptor. Nat Rev Neurosci 6:565-575.
Belmonte MK, Bourgeron T (2006): Fragile X syndrome and autism at the intersection of genetic and neural networks. Nat Neurosci 9: $1221-1226$

Ben-Ari Y (2002): Excitatory actions of gaba during development: the nature of the nurture. Nat Rev Neurosci 3:726-739.

Berry-Kravis E (2002): Epilepsy in fragile X syndrome. Dev Med Child Neurol 44:724728

Berry-Kravis E, Raspa M, Loggin-Hester L, Bishop E, Holiday D, Bailey DB (2010): Seizures in fragile $\mathrm{X}$ syndrome: characteristics and comorbid diagnoses. Am J Intellect Dev Disabil 115:461-472.

-Bettler B, Kaupmann K, Mosbacher J, Gassmann M (2004): Molecular structure and physiological functions of $\mathrm{GABA}(\mathrm{B})$ receptors. Physiol Rev 84:835-867.

-Biagini G, Panuccio G, Avoli M (2010): Neurosteroids and epilepsy. Curr Opin Neurol 23: 170-176.

Blundell J, Tabuchi K, Bolliger MF, Blaiss CA, Brose N, Liu X, Südhof TC, Powell CM (2009): Increased anxiety-like behavior in mice lacking the inhibitory synapse cell adhesion molecule neuroligin 2. Genes Brain Behav 8:114-126.

Bosman LW, Heinen K, Spijker S, Brussaard $A B$ (2005): Mice lacking the major adult GABAA receptor subtype have normal number of synapses, but retain juvenile IPSC kinetics until adulthood. J Neurophysiol 94: 338-346. 
-Bosman LW, Rosahl TW, Brussaard AB (2002): Neonatal development of the rat visual cortex: synaptic function of GABAA receptor alpha subunits. J Physiol (Lond) 545:169181.

Brown N, Kerby J, Bonnert TP, Whiting PJ, Wafford KA (2002): Pharmacological characterization of a novel cell line expressing human alpha(4)beta(3)delta GABA(A) receptors. $\mathrm{Br}$ J Pharmacol 136:965-974.

- Brown V, Jin P, Ceman S, Darnell JC, O’Donnell WT, Tenenbaum SA, Jin X, Feng Y, Wilkinson KD, Keene JD, Darnell RB, Warren ST (2001): Microarray identification of FMRPassociated brain mRNAs and altered mRNA translational profiles in fragile $\mathrm{X}$ syndrome. Cell 107:477-487.

Buckmaster PS, Jongen-Rêlo AL (1999): Highly specific neuron loss preserves lateral inhibitory circuits in the dentate gyrus of kainateinduced epileptic rats. J Neurosci 19:95199529.

- Budimirovic DB, Bukelis I, Cox C, Gray RM, Tierney E, Kaufmann WE (2006): Autism spectrum disorder in Fragile $\mathrm{X}$ syndrome: differential contribution of adaptive socialization and social withdrawal. Am J Med Genet A 140A:1814-1826.

Bureau I, Shepherd GM, Svoboda K (2008): Circuit and plasticity defects in the developing somatosensory cortex of FMR1 knock-out mice. J Neurosci 28:5178-5188.

-Cardin JA, Carlén M, Meletis K, Knoblich UZ, Deisseroth K, Tsai LH, Moore CI (2009): Driving fast-spiking cells induces gamma rhythm and controls sensory responses. $\mathrm{Na}-$ ture 459:663-667.

-Centonze D, Rossi S, Mercaldo V, Napoli I, Ciotti MT, De Chiara V, Musella A, Prosperetti C, Calabresi P, Bernardi G, Bagni C (2008): Abnormal striatal GABA transmission in the mouse model for the fragile X syndrome. Biol Psychiatry 63:963-973.

-Chang S, Bray SM, Li Z, Zarnescu DC, He C, Jin PW (2008): Identification of small molecules rescuing fragile $\mathrm{X}$ syndrome phenotypes in Drosophila. Nat Chem Biol 4:256-263.

-Chao HT, Chen H, Samaco RC, Xue M, Chahrour M, Yoo J, Neul JL, Gong S, Lu HC, Heintz N, Ekker M, Rubenstein JL, Noebels JL, Rosenmund C, Zoghbi HY (2010): Dysfunction in GABA signalling mediates autism-like stereotypies and Rett syndrome phenotypes. Nature 468:263-269.

-Chattopadhyaya B, Di Cristo G, Higashiyama H, Knott GWK, Welker E, Huang ZJ (2004): Experience and activity-dependent maturation of perisomatic GABAergic innervation in primary visual cortex during a postnatal critical period. J Neurosci 24:9598-9611.

- Chattopadhyaya B, Di Cristo G, Wu CZ, Knott GWK, Fu Y, Palmiter RDH (2007): GAD67mediated GABA synthesis and signaling regulate inhibitory synaptic innervation in the visual cortex. Neuron 54:889-903.
Chih B, Engelman H, Scheiffele P (2005): Control of excitatory and inhibitory synapse formation by neuroligins. Science 307:13241328.

-Chiron C, Dumas C, Jambaqué I, Mumford J, Dulac O (1997): Randomized trial comparing vigabatrin and hydrocortisone in infantile spasms due to tuberous sclerosis. Epilepsy Res 26:389-395.

-Christie SB, Akins MR, Schwob JE, Fallon JR (2009): The FXG: a presynaptic fragile X granule expressed in a subset of developing brain circuits. J Neurosci 29:1514-1524.

Chuang SC, Zhao W, Bauchwitz R, Yan Q, Bianchi R, Wong RK (2005): Prolonged epileptiform discharges induced by altered group I metabotropic glutamate receptor-mediated synaptic responses in hippocampal slices of a fragile $\mathrm{X}$ mouse model. J Neurosci 25: 8048-8055.

-Chubykin AA, Atasoy D, Etherton MR, Brose N, Kavalali ET, Gibson JR, Südhof TC (2007): Activity-dependent validation of excitatory versus inhibitory synapses by neuroligin-1 versus neuroligin-2. Neuron 54:919-931.

Comery TA, Harris JB, Willems PJ, Oostra BA, Irwin SA, Weiler IJ, Greenough WT (1997): Abnormal dendritic spines in fragile $\mathrm{X}$ knockout mice: maturation and pruning deficits. Proc Natl Acad Sci USA 94:54015404.

Cossart R, Dinocourt C, Hirsch JC, MerchanPerez A, De Felipe JB-A, Esclapez M, Bernard C (2001): Dendritic but not somatic GABAergic inhibition is decreased in experimental epilepsy. Nat Neurosci 4:52-62.

-Curia G, Papouin T, Sequela P, Avoli M (2008): Downregulation of tonic GABAergic inhibition in a mouse model of fragile $\mathrm{X}$ syndrome. Cereb Cortex 19:1515-1520.

Dahlhaus R, El-Husseini A (2010): Altered neuroligin expression is involved in social deficits in a mouse model of the fragile $\mathrm{X}$ syndrome. Behav Brain Res 208:96-105.

Dani VS, Chang Q, Maffei A, Turrigiano GG, Jaenisch R, Nelson SB (2005): Reduced cortical activity due to a shift in the balance between excitation and inhibition in a mouse model of Rett syndrome. Proc Natl Acad Sci USA 102:12560-12565.

- Darnell JC, Jensen KB, Jin P, Brown V, Warren ST, Darnell SB (2001): Fragile X mental retardation protein targets G quartet mRNAs important for neuronal function. Cell 107:555557.

Deacon S, Staner L, Staner C, Legters A, Loft H, Lundahl J (2007): Effect of short-term treatment with gaboxadol on sleep maintenance and initiation in patients with primary insomnia. Sleep 30:281-287.

De Felipe J, Marco P, Fairén A, Jones EG (1997): Inhibitory synaptogenesis in mouse somatosensory cortex. Cereb Cortex 7:619-634.

De Rubeis S, Bagni C (2010): Fragile X mental retardation protein control of neuronal mRNA metabolism: insights into mRNA stability. Mol Cell Neurosci 43:43-50.
Desai NS, Casimiro TM, Gruber SM, Vanderklish PW (2006): Early postnatal plasticity in neocortex of Fmrl knockout mice. J Neurophysiol 96:1734-1745.

de Vries BB, Halley DJ, Oostra B, Niermeijer MF (1998): The fragile X syndrome. J Med Genet 35:579-589.

Devys D, Lutz Y, Rouyer N, Bellocq JP, Mandel JL (1993): The FMR-1 protein is cytoplasmic, most abundant in neurons and appears nor$\mathrm{mal}$ in carriers of a fragile $\mathrm{X}$ premutation. Nat Genet 4:335-340.

D'Hulst C, De Geest N, Reeve SP, Van Dam D, De Deyn PP, Hassan BA, Kooy RF (2006): Decreased expression of the GABAa receptor in fragile X syndrome. Brain Res 1121: 238-245.

D'Hulst C, Heulens I, Brouwer JR, Willemsen R, De Geest N, Reeve SP, De Deyn PP, Hassan BA, Kooy RF (2009): Expression of the GABAergic system in animal models for fragile $\mathrm{X}$ syndrome and fragile $\mathrm{X}$ associated tremor/ataxia syndrome (FXTAS). Brain Res 1253:176-183.

Dolen G, Bear MF (2008): Role for metabotropic glutamate receptor 5 (mGluR5) in the pathogenesis of fragile $\mathrm{X}$ syndrome. J Physiol (Lond) 586:1502-1508.

Dunning DD, Hoover CL, Soltesz I, Smith MAOD, (1999): GABA(A) receptor-mediated miniature postsynaptic currents and alpha-subunit expression in developing cortical neurons. J Neurophysiol 82:3286-3297.

-Ehrlich I, Humeau Y, Grenier FC, Herry C, Luthi A (2009): Amygdala inhibitory circuits and the control of fear memory. Neuron 62:757771.

El Idrissi A, Boukarrou L, Dokin C, Brown WT (2009): Taurine improves congestive functions in a mouse model of fragile $\mathrm{X}$ syndrome. Adv Exp Med Biol 643:191-198.

El Idrissi A, Ding XH, Scalia J, Trenkner E, Brown WT, Dobkin C (2005): Decreased GABA(A) receptor expression in the seizure-prone fragile X mouse. Neurosci Lett 377:141-146.

El Idrissi A, L'Amoreaux WJ (2008): Selective resistance of taurine-fed mice to isoniazidepotentiated seizures: in vivo functional test for the activity of glutamic acid decarboxylase. Neuroscience 156:693-699.

-El Idrissi A, Yan X, Sidime F, L'Amoreaux W (2010): Neuro-endocrine basis for altered plasma glucose homeostasis in the Fragile X mouse. J Biomed Sci 17(suppl 1):S8.

Erickson CA, Weng N, Weiler IJ, Greenough WT, Stigler KA, Wink LKM (2010): Openlabel riluzole in fragile $\mathrm{X}$ syndrome. Brain Res 2011;1380:264-270.

-Farrant M, Nusser Z (2005): Variations on an inhibitory theme: phasic and tonic activation of GABA(A) receptors. Nat Rev Neurosci 6: 215-229.

-Feng Y, Gutekunst CA, Eberhart DE, Yi H, Warren ST, Hersch SM (1997): Fragile X mental retardation protein: nucleocytoplasmic shuttling and association with somatodendritic ribosomes. J Neurosci 17:1539-1547. 
-French JA, Mosier M, Walker S, Sommerville K, Sussman N (1996): A double-blind, placebocontrolled study of vigabatrin three g/day in patients with uncontrolled complex partial seizures. Vigabatrin Protocol 024 Investigative Cohort. Neurology 46:54-61.

-Frisén L, Malmgren K (2003): Characterization of vigabatrin-associated optic atrophy. Acta Ophthalmol Scand 81:466-473.

Fritschy JM, Brunig I (2003): Formation and plasticity of GABAergic synapses: physiological mechanisms and pathophysiological implications. Pharmacol Ther 98:299-323.

-Fritschy JM, Johnson DK, Mohler H, Rudolph U (1998): Independent assembly and subcellular targeting of GABA(A)-receptor subtypes demonstrated in mouse hippocampal and olfactory neurons in vivo. Neurosci Lett 249: 99-102.

-Fritschy JM, Paysan J, Enna A, Mohler H (1994): Switch in the expression of rat GABAA-receptor subtypes during postnatal development: an immunohistochemical study. J Neurosci 14:5302-5324.

Galarreta M, Hestrin S (1999): A network of fastspiking cells in neocortex connected by electrical synapses. Nature 402:72-75.

Galvez R, Gopal AR, Greenough WT (2003): Somatosensory cortical barrel dendritic abnormalities in a mouse model of the fragile $\mathrm{X}$ mental retardation syndrome. Brain Res 971: 83-89.

-Gantois I, Vandesompele J, Speleman F, Reyniers E, D'Hooge R, Severijnen LA, Willemsen R, Tassone F, Kooy RF (2006): Expression profiling suggests underexpression of the GABA(A) receptor subunit delta in the fragile $\mathrm{X}$ knockout mouse model. Neurobiol Dis 21:346-357.

-Gibson JR, Bartley AF, Hays SA, Huber KM (2008): Imbalance of neocortical excitation and inhibition and altered UP states reflect network hyperexcitability in the mouse model of fragile X syndrome. J Neurophysiol 100:2615-2626

Gibson JR, Beierlein M, Connors BW (1999): Two networks of electrically coupled inhibitory neurons in neocortex. Nature 402:75-79.

Gibson JR, Huber KM, Südhof T (2009): Neuroligin-2 deletion selectively decreases inhibitory synaptic transmission originating from fast-spiking but not from somatostatin-positive interneurons. J Neurosci 29:1388313897.

Glykys J, Mody I (2006): Hippocampal network hyperactivity after selective reduction of tonic inhibition in GABA A receptor alpha5 subunit-deficient mice. J Neurophysiol 95: 2796-2807.

Glykys J, Mody I (2007): Activation of GABAA receptors: views from outside the synaptic cleft. Neuron 56:763-770.

-Gogolla N, Leblanc JJ, Quast KB, Südhof T, Fagiolini M, Hensch TK (2009): Common circuit defect of excitatory-inhibitory balance in mouse models of autism. J Neurodev Disord 1:172-181.
Golshani P, Truong H, Jones EG (1997): Developmental expression of GABA(A) receptor subunit and GAD genes in mouse somatosensory barrel cortex. J Comp Neurol 383: 199-219.

Gothelf D, Furfaro JA, Hoeft F, Eckert MA, Hall SS, O’Hara R, Erba HW, Ringel J, Hayashi KM, Patnaik S, Golianu B, Kraemer HC, Thompson PM, Piven J, Reiss AL (2008): Neuroanatomy of fragile $\mathrm{X}$ syndrome is associated with aberrant behavior and the fragile X mental retardation protein (FMRP). Ann Neurol 63:40-51.

Gruss M, Braun K (2004): Age- and region-specific imbalances of basal amino acids and monoamine metabolism in limbic regions of female Fmrl knock-out mice. Neurochem Int 45:81-88.

-Hagerman RJ, Berry-Kravis E, Kaufmann WE, Ono MY, Tartaglia N, Lachiewicz A, Kronk R, Delahunty C, Hessl D, Visootsak J, Picker J, Gane L, Tranfaglia M (2009): Advances in the treatment of fragile X syndrome. Pediatrics 123:378-390.

Hagerman PJ, Stafstrom CE (2009): Origins of epilepsy in fragile $\mathrm{X}$ syndrome. Epilepsy Curr 9:108-112.

Harlow EG, Till SM, Russell TA, Wijetunge LS, Kind P, Contractor A (2010): Critical period plasticity is disrupted in the barrel cortex of Fmrl knockout mice. Neuron 65:385-398.

- Haydar TF, Wang F, Schwartz ML, Rakic P (2000): Differential modulation of proliferation in the neocortical ventricular and subventricular zones. J Neurosci 20:5764-5774.

Heinen K, Bosman LW, Spijker S, van Pelt J, Smit $\mathrm{AB}$, Voorn P, Baker RE, Brussaard AB (2004): GABAA receptor maturation in relation to eye opening in the rat visual cortex. Neuroscience 124:161-171.

Hennou S, Khalilov I, DIabira D, Ben-Ari Y, Gozlan H (2002): Early sequential formation of functional GABA(A) and glutamatergic synapses on CA1 interneurons of the rat foetal hippocampus. Eur J Neurosci 16:197-208.

Hevers W, Lüddens H (1998): The diversity of GABAA receptors. Pharmacological and electrophysiological properties of GABAA channel subtypes. Mol Neurobiol 18:35-86.

-Hinds HL, Ashley CT, Sutcliffe JS, Nelson DL, Warren ST, Housman DE, Schalling $M$ (1993): Tissue specific expression of FMR-1 provides evidence for a functional role in fragile X syndrome. Nat Genet 3:36-43.

Hines RM, Wu L, Hines DJ, Steenland H, Mansour S, Dahlhaus R, Singaraja RR, Cao X, Sammler E, Hormuzdi SG, Zhuo M, El-Husseini A (2008): Synaptic imbalance, stereotypies, and impaired social interactions in mice with altered neuroligin 2 expression. J Neurosci 28:6055-6067.

Hoeft F, Hernandez A, Parthsarathy S, Watson CL, Hall SS, Reiss AL (2007): Fronto-striatal dysfunction and potential compensatory mechanisms in male adolescents with fragile X syndrome. Hum Brain Mapp 28:543-554.
Hollrigel GS, Soltesz I (1997): Slow kinetics of miniature IPSCs during early postnatal development in granule cells of the dentate gyrus. J Neurosci 17:5119-5128.

Huang ZJ (2009): Activity-dependent development of inhibitory synapses and innervation pattern: role of GABA signalling and beyond. J Physiol (Lond) 587:1881-1888.

Huber KM, Gallagher SM, Warren ST, Bear MF (2002): Altered synaptic plasticity in a mouse model of fragile X mental retardation. Proc Natl Acad Sci USA 99:7746-7750.

-Huntsman MM, Huguenard JR (2000): Nucleusspecific differences in GABA(A)-receptormediated inhibition are enhanced during thalamic development. J Neurophysiol 83: 350-358.

-Huntsman MM, Muñoz A, Jones EG (1999): Temporal modulation of $\mathrm{GABA}_{\mathrm{A}}$ receptor subunit gene expression in developing monkey cerebral cortex. Neuroscience 91:12231245.

- Irwin SA, Patel B, Idupulapati M, Harris JB, Crisostomo RA, Larsen BP, Kooy RF, Willems PJ, Cras P, Kozlowski PB, Swain RA, Weiler IJ, Greenough WT (2001): Abnormal dendritic spine characteristics in the temporal and visual cortices of patients with fragile-X syndrome: a quantitative examination. Am J Med Genet 98:161-167.

Jacquemont S, Curie A, des Portes V, Torrioli MG, Berry-Kravis E, Hagerman RJ, Ramos FJ, Cornish K, He Y, Paulding C, Neri G, Chen F, Hadjikhani N, Martinet D, Meyer J, Beckmann JS, Delange K, Brun A, Bussy G, Gasparini F, Hilse T, Floesser A, Branson J, Bilbe G, Johns D, Gomez-Mancilla B (2011): Epigenetic modification of the FMR1 gene in fragile $\mathrm{X}$ syndrome is associated with differential response to the mGluR5 antagonist AFQ056. Sci Transl Med 2011;3:64ra1.

Jahn K, Schlesinger F, Jin LJ, Dengler R, Bufler J, Krampfl K (2008): Molecular mechanisms of interaction between the neuroprotective substance riluzole and GABA(A)-receptors. Naunyn Schmiedebergs Arch Pharmacol 378:53-63.

Kawaguchi Y, Kubota Y (1997): GABAergic cell subtypes and their synaptic connections in rat frontal cortex. Cereb Cortex 7:476-486.

- Kerner JA, Standaert DG, Penney JBJ, Young AB, Labdwehrmeyer GB (1997): Expression of group one metabotropic glutamate receptor subunit mRNAa in neurochemically identified neurons in the rat neostriatum, neocortex, and hippocampus. Mol Brain Res 48: 259-269.

Kirischuk S, Jüttner R, Grantyn R (2005): Timematched pre- and postsynaptic changes of GABAergic synaptic transmission in the developing mouse superior colliculus. J Physiol (Lond) 563:795-807.

Klausberger T, Roberts JD, Somogyi P (2002): Cell type- and input-specific differences in the number and subtypes of synaptic GABA(A) receptors in the hippocampus. J Neurosci 22:2513-2521. 
- Kobayashi M, Hamada T, Kogo M, Yanagawa Y, Obata K, Kang Y (2008): Developmental profile of $\mathrm{GABA}_{\mathrm{A}}$-mediated synaptic transmission in pyramidal cells of the somatosensory cortex. Eur J Pharmacol 28:849-861.

L'Amoreaux WJ, Marsillo A, El Idrissi A (2010): Pharmacological characterization of GABAA receptors in taurine-fed mice. J Biomed Sci 17(suppl 1):S14.

Laurie DJ, Wisden W, Seeburg PH (1992): The distribution of thirteen GABAA receptor subunit mRNAs in the rat brain. III. Embryonic and postnatal development. J Neurosci 12:4151-4172.

Ledoux J (2003): The emotional brain, fear, and the amygdala. Cell Mol Neurobiol 23:727738.

Lewis DA, Hashimoto T, Volk DW (2005): Cortical inhibitory neurons and schizophrenia. Nat Rev Neurosci 6:312-324.

- Li J, Pelletier MR, Perez Velaquez JL, Carlen PL (2002): Reduced cortical synaptic plasticity and GluR1 expression associated with fragile $\mathrm{X}$ mental retardation protein deficiency. Mol Cell Neurosci 19:138-151.

Li P, Rudolph U, Huntsman MM (2009): Longterm sensory deprivation selectively rearranges functional inhibitory circuits in mouse barrel cortex. Proc Natl Acad Sci USA 106:12156-12161.

- Li RW, Yu W, Christie S, Miralles CP, Bai J, Loturco JJ, De Blas AL (2005): Disruption of postsynaptic GABA receptor clusters leads to decreased GABAergic innervation of pyramidal neurons. J Neurochem 95:756-770.

Liao L, Park SK, Xu T, Vanderklish P, Yates JRI (2008): Quantitative proteomic analysis of primary neurons reveals diverse changes in synaptic protein content in fmrl knockout mice. Proc Natl Acad Sci USA 105:15281-15286.

-López-Bendito G, Luján R, Shigemoto R, Ganter P, Paulson O, Molnár Z (2003): Blockade of $\mathrm{GABA}(\mathrm{B})$ receptors alters the tangential migration of cortical neurons. Cereb Cortex 13: 932-942.

- LoTurco JJ, Owens DF, Heath MJ, Davis MB, Kriegstein AR (1995): GABA and glutamate depolarize cortical progenitor cells and inhibit DNA synthesis. Neuron 15:1287-1298.

Lundahl J, Staner L, Staner C, Loft H, Deacon S (2007): Short-term treatment with gaboxadol improves sleep maintenance and enhances slow wave sleep in adult patients with primary insomnia. Psychopharmacology 195: 139-146.

- Maccarrone M, Rossi S, Bari M, De Chiara V, Rapino C, Bernardi G, Bagni C, Centonze D (2010): Abnormal mGlu 5 receptor/endocannabinoid coupling in mice lacking FMRP and BC1 RNA. Neuropsychopharmacology 35:1500-1509.

Maffei A, Turrigiano GG (2008): Multiple modes of network homeostasis in visual cortical layer 2/3. J Neurosci 28:4377-4384.

-Maffei A, Nataraj K, Nelson SB, Turrigiano GG (2006): Potentiation of cortical inhibition by visual deprivation. Nature 443:81-84.
Manent JB, Demarque M, Jorquera I, Pellegrino C, Ben-Ari Y, Aniksztejn L, Represa A (2005): A noncanonical release of GABA and glutamate modulates neuronal migration. J Neurosci 25:4755-4765.

- Mantz J, Laudenbach V, Lecharny JB, Henzel D, Desmonts JM (1994): Riluzole, a novel antiglutamate, blocks GABA uptake by striatal synaptosomes. Eur J Pharmacol 257:R7-R8.

Marín O, Yaron A, Bagri A, Tessier-Lavigne M, Rubenstein JL (2001): Sorting of striatal and cortical interneurons regulated by semaphorin-neuropilin interactions. Science 293: 872-875.

-Markram H, Toledo-Rodriguez M, Wang Y, Gupta A, Silberberg G, Wu C (2004): Interneurons of the neocortical inhibitory system. Nat Rev Neurosci 5:793-807.

- McNaughton CH, Moon J, Strawderman MS, Maclean KN, Evans J, Strupp BJ (2008): Evidence for social anxiety and impaired social cognition in a mouse model of fragile X syndrome. Behav Neurosci 122:293-300.

-Medrihan L, Tantalaki E, Aramuni G, Sargysan V, Dudanova IM, Zhang W (2008): Early defects of GABAergic synapses in the brain stem of a MeCP2 mouse model of Rett syndrome. J Neurophysiol 99:112-121.

Menon V, Leroux J, White CD, Reiss AL (2004): Frontostriatal deficits in fragile X syndrome: relation to FMR1 gene expression. Proc Natl Acad Sci USA 101:3615-3620.

Micheva KD, Beaulieu C (1995): An anatomical substrate for experience-dependent plasticity of the rat barrel field cortex. Proc Natl Acad Sci USA 92:11834-11838.

Micheva KD, Beaulieu C (1996): Quantitative aspects of synaptogenesis in the rat barrel field cortex with special reference to GABA circuitry. J Comp Neurol 373:340-354.

Mihalek RM, Banerjee PK, Korpi ER, Quinlan JJ, Firestone LL, Mi ZP, Lagenaur C, Tretter V, Sieghart W, Anagnostaras SG, Sage JR, Fanselow MS, Guidotti A, Spigelman I, Li Z, DeLorey TM, Olsen RW, Homanics GE (1999): Attenuated sensitivity to neuroactive steroids in gamma-aminobutyrate type A receptor delta subunit knockout mice. Proc Natl Acad Sci USA 96:12905-12910.

- Miller LJ, McIntosh DN, McGrath J, Shyu V, Lampe M, Taylor AK, Tassone F, Neitzel K, Stackhouse T, Hagerman RJ (1999): Electrodermal responses to sensory stimuli in individuals with fragile $\mathrm{X}$ syndrome: a preliminary report. Am J Med Genet 83:268-279.

Misgeld U, Bijak M, Jarolimek W (1995): A physiological role for $\mathrm{GABAB}$ receptors and the effects of baclofen in the mammalian central nervous system. Prog Neurobiol 46:423462.

-Miyashiro KY, Beckel-Mitchener A, Purk TP, Becker KG, Barret T, Liu L, Carbonetto S, Weiler IJ, Greenough WT, Eberwine J (2003): RNA cargoes associating with FMRP reveal deficits in cellular functioning in Fmr1 null mice. Neuron 37:417-431.
Moretti P, Zoghbi HY (2006): MeCP2 dysfunction in Rett syndrome and related disorders. Curr Opin Genet Dev 16:276-281.

Moy SS, Nadler JJ (2008): Advances in behavioral genetics: mouse models of autism. Mol Psychiatry 13:4-26.

Moy SS, Nadler JJ, Young NB, Nonneman RJ, Grossman AW, Murphy DL, D'Ercole AJ, Crawley JN, Magnuson TR, Lauder JM (2009): Social approach in genetically engineered mouse lines relevant to autism. Genes Brain Behav 8:129-142.

Muller JF, Mascagni F, McDonald AJ (2006): Pyramidal cells of the rat basolateral amygdala: synaptology and innervation by parvalbumin-immunoreactive interneurons. J Comp Neurol 494:635-650.

-Muller JF, Mascagni F, McDonald AJ (2007): Postsynaptic targets of somatostatin-containing interneurons in the rat basolateral amygdala. J Comp Neurol 500:513-529.

-Musumeci SA, Colognola RM, Ferri R, Gigli GL, Petrella MA, Sanfilippo S, Bergonzi P, Tassinari CA (1988): Fragile-X syndrome: a particular epileptogenic EEG pattern. Epilepsia 29:41-47.

-Musumeci SA, Hagerman RJ, Ferri R, Bosco P, Dalla Bernardina B, Tassinari CA, De Sarro GB, Elia M (1999): Epilepsy and EEG findings in males with fragile $\mathrm{X}$ syndrome. Epilepsia 40:1092-1099.

Nemeroff C (2003): The role of GABA in the pathophysiology and treatment of anxiety disorders. Psychopharmacol Bull 37:133-146.

- Nielsen EB, Suzdak PD, Andersen KE, Knutsen LJ, Sonnewald U, Braestrup C (1991): Characterization of tiagabine (NO-328), a new potent and selective GABA uptake inhibitor. Eur J Pharmacol 196:257-266.

- Nusser Z, Sieghart W, Benke D, Fritschy JM, Somogyi P (1996): Differential synaptic localization of two major gamma-aminobutyric acid type A receptor alpha subunits on hippocampal pyramidal cells. Proc Natl Acad Sci USA 93:11939-11944.

Nyiri G, Freund TF, Somogyi P (2001): Inputdependent synaptic targeting of alpha(2)subunit-containing $\mathrm{GABA}(\mathrm{A})$ receptors in synapses of hippocampal pyramidal cells of the rat. Eur J Neurosci 13:428-442.

-Olmos-Serrano JL, Paluszkiewicz SM, Kaufmann WE, Corbin JG, Huntsman MM (2010): Defective GABAergic neurotransmission and pharmacological rescue of neuronal hyperexcitability in the amygdala in a mouse model of fragile $x$ syndrome. J Neurosci 30:9929-9938.

-Ortinski PI, Lu C, Takagaki K, Fu Z, Vicini S (2004): Expression of distinct alpha subunits of GABAA receptor regulates inhibitory synaptic strength. J Neurophysiol 92:17181727.

Pacey LK, Heximer SP, Hampson DR (2009): Increased GABA(B) receptor-mediated signaling reduces the susceptibility of fragile $\mathrm{X}$ knockout mice to audiogenic seizures. Mol Pharmacol 76:18-24. 
- Padgett CL, Slesinger PA (2010): GABAB receptor coupling to G-proteins and ion channels. Adv Pharmacol 58:123-147.

- Paradee W, Melikian HE, Rasmussen DL, Kenneson A, Conn PJ, Warren ST (1999): Fragile $\mathrm{X}$ mouse: strain effects of knockout phenotype and evidence suggesting deficient amygdala function. Neuroscience 94:185192.

- Pascual M, Pozas E, Soriano E (2005): Role of class 3 semaphorins in the development and maturation of the septohippocampal pathway. Hippocampus 15:184-202.

- Porter JT, Johnson CK, Agmon A (2001): Diverse types of interneurons generate thalamusevoked feedforward inhibition in the mouse barrel cortex. J Neurosci 21:2699-2710.

-Poulopoulos A, Aramuni G, Meyer G, Soykan T, Hoon M, Papadopoulos T, Zhang M, Paarmann I, Fuchs C, Harvey K, Jedlicka P, Schwarzacher SW, Betz H, Harvey RJ, Brose N, Zhang W, Varoqueaux F (2009): Neuroligin 2 drives postsynaptic assembly at perisomatic inhibitory synapses through gephyrin and collybistin. Neuron 63:628642.

Reddy DS (2010): Neurosteroids: endogenous role in the human brain and therapeutic potentials. Prog Brain Res 186:113-137.

Reiss AL, Abrams MT, Greenlaw R, Freund L, Denckla MB (1995): Neurodevelopmental effects of the FMR-1 full mutation. Nat Med 1:159-167.

Reiss AL, Lee J, Freund L (1994): Neuroanatomy of fragile X syndrome: the temporal lobe. Neurology 44:1317-1324.

- Rivera C, Voipio J, Payne JA, Ruusuvuori E, Lahtinen H, Lamsa K, Pirvola U, Saarma M, Kaila K (1999): The $\mathrm{K}^{+} / \mathrm{Cl}^{-}$co-transporter KCC2 renders GABA hyperpolarizing during neuronal maturation. Nature 397:251255.

Rubenstein JLR, Merzenich MM (2003): Model of autism: increased ratio of excitation/inhibition in key neural systems. Genes Brain Behav 2:255-267.

-Rudolph U, Möhler H (2006): GABA-based therapeutic approaches: GABAA receptor subtype functions. Curr Opin Pharmacol 6:1823.

-Schütt J, Falley K, Richter D, Kreienkamp HJ, Kindler S (2009): Fragile X mental retardation protein regulates the levels of scaffold proteins and glutamate receptors in postsynaptic densities. J Biol Chem 284:2547925487.

-Selby L, Zhang C, Sun QQ (2007): Major defects in neocortical GABAergic circuits in mice lacking the fragile $\mathrm{X}$ mental retardation protein. Neurosci Lett 412:227-232.

-Semyanov A, Walker MC, Kullmann DM, Silver RA (2004): Tonically active GABA A receptors: modulating gain and maintaining the tone. Trends Neurosci 27:262-269.
Sieghart W, Sperk G (2002): Subunit composition, distribution and function of GABA(A) receptor subtypes. Curr Top Med Chem 2: 795-816.

Sohal VS, Zhang F, Yizhar O, Deisseroth K (2009): Parvalbumin neurons and gamma rhythms enhance cortical circuit performance. Nature 459:698-702.

Somogyi P, Klausberger T (2005): Defined types of cortical interneurone structure space and spike timing in the hippocampus. J Physiol (Lond) 562:9-26.

-Somogyi P, Tamás G, Lujan R, Buhl EH (1998): Salient features of synaptic organisation in the cerebral cortex. Brain Res Rev 26:113135.

Stinehelfer S, Vruwink M, Burette A (2000): Immunolocalization of mGluRlalpha in specific populations of local circuit neurons in the cerebral cortex. Brain Res 861:37-44.

-Südhof T (2008): Neuroligins and neurexins link synaptic function to cognitive disease. $\mathrm{Na}$ ture 455:903-911.

Sun QQ, Zhang Z, Jiao Y, Zhang C, Szabo G, Erdelyi F (2009): Differential metabotropic glutamate receptor expression and modulation in two neocortical inhibitory networks. J Neurophysiol 101:2679-2692.

-Suvrathan A, Hoeffer CA, Wong H, Klann E, Chattarji S (2010): Characterization and reversal of synaptic defects in the amygdala in a mouse model of fragile X syndrome. Proc Natl Acad Sci USA 107:11591-11596.

- Tamamaki N, Fujimori K, Nojyo Y, Kaneko T, Takauji R (2003): Evidence that Sema3A and Sema3F regulate the migration of GABAergic neurons in the developing neocortex. J Comp Neurol 455:238-248.

Tamanini F, Willemsen R, van Unen L, Bontekoe C, Galjaard H, Oostra B, Hoogeveen AT (1997): Differential expression of FMR1, FXR1 and FXR2 proteins in human brain and testis. Hum Mol Genet 6:1315-1322.

Trigo FF, Marty A, Stell BM (2008): Axonal GABAA receptors. Eur J Neurosci 28:841848.

- Tyzio R, Represa A, Jorquera I, Ben-Ari Y, Gozlan H, Aniksztejn L (1999): The establishment of GABAergic and glutamatergic synapses on CA1 pyramidal neurons is sequential and correlates with the development of the apical dendrite. J Neurosci 19: 10372-10382.

Varoqueaux F, Jamain S, Brose N (2004): Neuroligin 2 is exclusively localized to inhibitory synapses. Eur J Cell Biol 83:449-456.
Verkerk A, Pieretti M, Sutcliffe JS, Fu YH, Kuhl DP, Pizzuti A, Reiner O, Richards S, Victoria MF, Zhang FP, Eussen BE, van Ommen GB, Blonden LAJ, Riggins GJ, Chastain JL, Kunst CB, Galjaard H, Caskey CT, Nelson DL, Oostra BA, Warren ST (1991): Identification of a gene (FMR-1) containing a CGG repeat coincident with a breakpoint cluster region exhibiting length variation in fragile X syndrome. Cell 65:905-914

Vicini S, Ferguson C, Prybylowski K, Kralic J, Morrow AL, Homanics GE (2001): GABA(A) receptor alphal subunit deletion prevents developmental changes of inhibitory synaptic currents in cerebellar neurons. J Neurosci 21:3009-3016.

-Wang C, Shimizu-Okabe C, Watanabe K, Okabe A, Matsuzaki H, Ogawa T, Mori N, Fukuda A, Sato K (2002): Developmental changes in $\mathrm{KCC} 1, \mathrm{KCC} 2$, and NKCC1 mRNA expressions in the rat brain. Dev Brain Res 139:59-66.

Wang DD, Kriegstein AR (2008): GABA regulates excitatory synapse formation in the neocortex via NMDA receptor activation. J Neurosci 28:5547-5558.

Wang DD, Kriegstein AR (2009): Defining the role of GABA in cortical development. J Physiol (Lond) 587:1873-1879.

Wang H, Ku L, Osterhout DJ, Li W, Ahmadian A, Liang Z, Feng Y (2004): Developmentallyprogrammed FMRP expression in oligodendrocytes: a potential role of FMRP in regulating translation in oligodendroglia progenitors. Hum Mol Genet 13:79-89.

-Wang XJ (2010): Neurophysiological and computational principles of cortical rhythms in cognition. Physiol Rev 90:1195-1268.

Wilson BM, Cox CL (2007): Absence of metabotropic glutamate receptor-mediated plasticity in the neocortex of fragile $\mathrm{X}$ mice. Proc Natl Acad Sci USA 104:2454-2459.

Wilson RI, Nicoll RA (2002): Endocannabinoid signaling in the brain. Science 296:678-682.

Yamada J, Okabe A, Toyoda H, Kilb W, Luhmann HJ, Fukuda A (2004): $\mathrm{Cl}^{-}$uptake promoting depolarizing GABA actions in immature rat neocortical neurones is mediated by NKCC1. J Physiol (Lond) 557:829-841.

- Yan QJ, Rammal M, Tranfaglia M, Bauchwitz RP (2005): Suppression of two major fragile $X$ syndrome mouse model phenotypes by the mGluR5 antagonist MPEP. Neuropharmacology 49:1053-1066.

-Yu W, Jiang M, Miralles CP, Li RW, Chen G, De Blas AL (2007): Gephyrin clustering is required for the stability of GABAergic synapses. Mol Cell Neurosci 36:484-500.

-Zhang L, Alger BE (2010): Enhanced endocannabinoid signaling elevates neuronal excitability in fragile X syndrome. J Neurosci 30: 5724-5729.

Zoghbi HY (2003): Postnatal neurodevelopmental disorders: meeting at the synapse? Science 302:826-830. 